\title{
Cellular Therapy with Engineered T Cells, Efficacy and Side Effects
}

\author{
Attilio Bondanza, Chiara Bonini, Boris Fehse, \\ and Michael Hudecek
}

\subsection{Introduction}

The cellular basis of cancer immune surveillance, already hypothesized in ancient times, was only demonstrated with the advent of HSCT. Indeed, the discovery of the nature of GVHD and its antileukemic effects (Weiden et al. 1979) were followed by the first successful attempts of adoptive immunotherapy using donor leukocytes (Kolb et al. 1990).

\footnotetext{
A. Bondanza

Innovative Immunotherapies Unit, Division of Immunology, Transplantation and Infectious Diseases, University Vita-Salute San Raffaele and Ospedale San Raffaele Scientific Institute, Milan, Italy

C. Bonini $(\bowtie)$

Experimental Hematology Unit, Division of Immunology, Transplantation and Infectious Diseases, University Vita-Salute San Raffaele and Ospedale San Raffaele Scientific Institute, Milan, Italy

e-mail: bonini.chiara@hsr.it

B. Fehse

Research Department Cell and Gene Therapy, Department of Stem Cell Transplantation, University Medical Centre Hamburg-Eppendorf, Hamburg, Germany

M. Hudecek

Medizinische Klinik und Poliklinik II,

Universitätsklinikum Würzburg, Würzburg, Germany
}

To address the significant GVHD risk associated with allogeneic $\mathrm{T}$ cells, several approaches of T-cell manipulation were developed and tested (Table 60.1). Some of these strategies rely on the genetic manipulation of $\mathrm{T}$ cells. First, suicide gene therapy approaches were established to promote GVL and immune reconstitution while controlling GVHD.

More recently, strategies based on the genetic transfer of tumor-specific T-cell receptors (TCRs) or chimeric antigen receptors (CARs) were developed to improve antitumor efficiency of $\mathrm{T}$ cells. This chapter provides an overview of this vastly evolving area.

\subsection{Suicide Gene Therapy}

The transfer of a suicide gene into donor lymphocytes was designed and tested at preclinical and clinical level in the 1990s, with the aim of transferring the entire donor T-cell repertoire, inclusive of cancer and infectious specificities, to transplanted patients, while enabling the selective elimination of the transferred lymphocytes in case of GVHD (Bonini et al. 1997). The first suicide gene, and to date the most extensively tested in clinical trials, is thymidine kinase of herpes simplex virus (HSV-TK). HSV-TK expression confers selective sensitivity to the antiviral drug ganciclovir. Upon gene transfer, HSV-TK is stably expressed by donor $\mathrm{T}$ lymphocytes not interfering with their functionality. However, when 
Table 60.1 T-cell-based cellular therapy approaches to increase GVL/GVI while taming GVHD

\begin{tabular}{|c|c|c|}
\hline Strategy & Mechanism of action & References \\
\hline $\begin{array}{l}\text { Infusions of pathogen (i.e., } \\
\text { CMV, EBV)-specific T cells }\end{array}$ & $\begin{array}{l}\text { Isolation and infusion of } \mathrm{T} \text { cells specific for } \\
\text { opportunistic pathogens, to control post } \\
\text { transplant infectious morbidity and } \\
\text { mortality }\end{array}$ & $\begin{array}{l}\text { Riddell et al. (1992), Rooney et al. } \\
\text { (1995), Koehne et al. (2003) }\end{array}$ \\
\hline $\begin{array}{l}\text { Infusions of } \mathrm{T} \text { cells depleted } \\
\text { of alloreactive specificities }\end{array}$ & $\begin{array}{l}\text { In vitro activation of host-reactive } \mathrm{T} \text { cells } \\
\text { followed by their depletion, infusion of } \\
\text { remaining cells with the aim of promoting } \\
\text { immune reconstitution with a reduced GVHD } \\
\text { risk }\end{array}$ & $\begin{array}{l}\text { André-Schmutz et al. (2002), } \\
\text { Hartwig et al. (2008), Mielke et al. } \\
\text { (2008) }\end{array}$ \\
\hline Infusions of regulatory $\mathrm{T}$ cells & $\begin{array}{l}\text { Isolation and/or expansion T-cell subsets with } \\
\text { regulatory properties to promote immune } \\
\text { reconstitution with a reduced GVHD risk }\end{array}$ & $\begin{array}{l}\text { Groux et al. (1997), Chen et al. } \\
\text { (2003), Trenado et al. (2004), } \\
\text { Brunstein et al. (2011), Di Ianni } \\
\text { et al. (2011), Bacchetta et al. (2014) }\end{array}$ \\
\hline $\begin{array}{l}\text { Infusion of T cells depleted of } \\
\text { regulatory T cells }\end{array}$ & $\begin{array}{l}\text { Infusion of } \mathrm{T} \text { cells depleted of regulatory } \mathrm{T} \\
\text { cells to increase the antileukemic activity of } \\
\text { DLI }\end{array}$ & Maury et al. (2010) \\
\hline $\begin{array}{l}\text { Infusions of leukemia-specific } \\
\mathrm{T} \text { cells }\end{array}$ & $\begin{array}{l}\text { Isolation and infusion of } \mathrm{T} \text { cells specific for } \\
\text { leukemia-associated antigens to boost the } \\
\text { GVL potency of DLI }\end{array}$ & $\begin{array}{l}\text { Warren et al. (2010), Bornhauser } \\
\text { et al. (2011), Chapuis et al. (2013), } \\
\text { Comoli et al. (2017) }\end{array}$ \\
\hline $\begin{array}{l}\text { Infusion of alpha/beta } \\
\text { depleted T cells }\end{array}$ & $\begin{array}{l}\text { Infusion of a graft in vitro depleted of } \\
\text { conventional alpha/beta T cells, thus enriched } \\
\text { of gammadelta T cells, endowed with } \\
\text { antitumor activity and a low GVHD potential }\end{array}$ & $\begin{array}{l}\text { Lang et al. (2015), Airoldi et al } \\
\text { (2015), Mashan et al. (2016) }\end{array}$ \\
\hline $\begin{array}{l}\text { Infusion naïve-depleted T } \\
\text { cells }\end{array}$ & $\begin{array}{l}\text { Infusion of donor T-cell subsets in vitro } \\
\text { depleted of naïve cells, with the aim of } \\
\text { promoting immune reconstitution with a } \\
\text { reduced GVHD risk }\end{array}$ & Bleakley (2015) \\
\hline Infusions of CIK & $\begin{array}{l}\text { Infusions of in vitro activated donor CIK } \\
\text { cells to promote GVL and reduce the risk of } \\
\text { GVHD }\end{array}$ & Introna (2007), Introna (2010) \\
\hline Suicide gene therapy & $\begin{array}{l}\text { Donor lymphocytes are genetically } \\
\text { engineered to express a suicide gene and then } \\
\text { infused after HSCT to promote GVT and } \\
\text { immune reconstitution while selectively } \\
\text { controlling GVHD with the prodrug- } \\
\text { mediated activation of the suicide gene }\end{array}$ & $\begin{array}{l}\text { Bonini et al. (1997), Ciceri, Bonini } \\
\text { et al (2009), Di Stasi et al. (2011), } \\
\text { Zhan et al. (2013), Oliveira et al. } \\
\text { (2015) }\end{array}$ \\
\hline CAR/TCR T cells & $\begin{array}{l}\text { Lymphocytes are genetically engineered to } \\
\text { express a chimeric antigen receptor (CAR) or } \\
\text { a T-cell receptor (TCR) that confers to T cells } \\
\text { specificity for an antigen expressed by cancer } \\
\text { cells }\end{array}$ & $\begin{array}{l}\text { Kochenderfer et al. (2010), Porter } \\
\text { et al. (2011), Brentjens et al. (2013), } \\
\text { Morgan et al. (2006), Robbins et al. } \\
\text { (2011) }\end{array}$ \\
\hline
\end{tabular}

CIK-cytokine-activated killer

exposed to ganciclovir, highly proliferating HSV-TK expressing T cells (TK-cells) will die in a dose-dependent manner. Thus, if ganciclovir is administered during GVHD to patients treated with TK-cells, activated, highly proliferating alloreactive TK-cells will be eliminated. The HSV-TK/ganciclovir suicide system proved highly effective in controlling GVHD in several transplant settings (Table 60.2), including haploi- dentical HSCT (haplo-HSCT). After TCD haploHSCT, the infusion of TK-cells promoted broad and rapid immune reconstitution that, being associated to GVHD control, has led to abrogation of late transplant-related mortality (Ciceri et al. 2009). Overall, clinical results obtained with TK-cells led to their conditional approval by EMA in 2016, thus representing the first genetically engineered medicinal product approved for 
Table 60.2 Clinical trials of TK-suicide gene therapy in allogeneic HSCT

\begin{tabular}{|c|c|c|c|c|c|c|c|}
\hline $\begin{array}{l}\text { Clinical } \\
\text { application } \\
\text { (references) }\end{array}$ & $\begin{array}{l}\text { Suicide gene/ } \\
\text { marker gene }\end{array}$ & $\begin{array}{l}\text { Disease } \\
\text { indication }\end{array}$ & $\begin{array}{l}\text { Patients } \\
\text { treated }\end{array}$ & $\begin{array}{l}\mathrm{T} \text { cells } \\
\text { infused/ } \\
\mathrm{kg}\end{array}$ & $\begin{array}{l}\text { Clinical } \\
\text { response } \\
\text { (no. } \\
\text { patients) }\end{array}$ & $\begin{array}{l}\text { Incidence of } \\
\text { aGvHD/ } \\
\text { chronic no. } \\
\text { pts (grade) }\end{array}$ & $\begin{array}{l}\text { CR of } \\
\text { aGvHD } \\
\text { and } \\
\text { cGVHD to } \\
\text { GCV }\end{array}$ \\
\hline $\begin{array}{l}\text { To treat disease } \\
\text { relapse occurring } \\
\text { after HLA- } \\
\text { identical } \\
\text { allo-HSCT }\end{array}$ & $\begin{array}{l}\text { HSV- } \\
\text { TK/DLNGFr } \\
\text { HSV-TK/NeoR }\end{array}$ & $\begin{array}{l}\text { AML, CML, } \\
\text { CMML, MM, } \\
\text { NHL (adults) } \\
\text { AML, CML, } \\
\text { NHL (adults) }\end{array}$ & $\begin{array}{l}28 \\
34\end{array}$ & $\begin{array}{l}10^{6}-10^{8} \\
10^{6}-10^{8}\end{array}$ & $\begin{array}{l}15^{b} \\
9^{b}\end{array}$ & $\begin{array}{l}6(\mathrm{I}-\mathrm{III}) \\
2(\mathrm{I})\end{array}$ & $\begin{array}{l}5 / 5^{\mathrm{c}} \\
1 / 1\end{array}$ \\
\hline $\begin{array}{l}\text { Day } 0 \text { in TCD } \\
\text { allo-HSCT }\end{array}$ & HSV-TK/NeoR & $\begin{array}{l}\text { ALL, AML, } \\
\text { CML, MDS, } \\
\text { NHL, WD } \\
\text { (adults) }\end{array}$ & 15 & & $5^{b}$ & 6 (II-III) & $6 / 6$ \\
\hline $\begin{array}{l}\text { Day } 60 \text { in TCD } \\
\text { allo-HSCT }\end{array}$ & $\begin{array}{l}\text { HSV- } \\
\text { TK/DLNGFr }\end{array}$ & $\begin{array}{l}\text { AML, ALL, } \\
\text { MDS, CML } \\
\text { (adults) }\end{array}$ & 9 & & $7^{f}$ & 3 (I-II) & $1 / 1$ \\
\hline $\begin{array}{l}\text { Day } 42 \text { in TCD } \\
\text { haplo-HSCT }{ }^{\mathrm{g}}\end{array}$ & $\begin{array}{l}\text { HSV- } \\
\text { TK/ } \triangle \mathrm{LNGFr}\end{array}$ & $\begin{array}{l}\text { AML, MDS, } \\
\text { NHL (adults) }\end{array}$ & 40 & $10^{6}-10^{7}$ & $29^{\mathrm{h}}$ & 12 (I-IV) & $11 / 11^{\mathrm{i}}$ \\
\hline $\begin{array}{l}\text { Day } 1 \text { in TCD } \\
\text { haplo-HSCT }\end{array}$ & $\begin{array}{l}\text { HSV-TK-CD34 } \\
\text { fusion gene }\end{array}$ & $\begin{array}{l}\text { FA, ID, MDS } \\
\text { (pediatrics) }\end{array}$ & 3 & $10^{4}-10^{5}$ & $3 / 3^{\mathrm{h}}$ & 1 & - \\
\hline $\begin{array}{l}\text { Day 30-90 in } \\
\text { TCD } \\
\text { haplo-HSCT }{ }^{k}\end{array}$ & iCasp9/ $\triangle \mathrm{CD}^{1} 9^{\mathrm{l}}$ & $\begin{array}{l}\text { MDS, AML, } \\
\text { ALL } \\
\text { (pediatrics) }\end{array}$ & 10 & $10^{6}-10^{7}$ & $10^{\mathrm{h}}\left[5^{\mathrm{b}}\right]$ & 4 (I-II) & $4 / 4$ \\
\hline $\begin{array}{l}\text { Day } 13 \text { after } \\
\text { alpha/beta } \\
\text { depleted } \\
\text { haplo-HSCT }^{\mathrm{m}}\end{array}$ & iCasp9/ $\Delta$ CD19 & ALL (adult) & 1 & & 1 & $1(\mathrm{I})$ & 0 \\
\hline Total & & & 140 & & $79(56 \%)$ & 35 & $\begin{array}{l}28 / 28 \\
(100 \%)\end{array}$ \\
\hline
\end{tabular}

$G C V$ ganciclovir, Ne not evaluable

${ }^{a}$ Bonini et al. (1997), Ciceri et al. (2007), Onodera et al. (2008), Champlin et al. (1999), Munshi et al. (1997)

${ }^{\mathrm{b}} \mathrm{Clinical}$ outcome is measured as clinical response of the malignant disease

${ }^{\mathrm{c}}$ One patient with GVHD achieved CR after GCV administration and immunosuppressive drugs

${ }^{\mathrm{d}}$ Tiberghien et al. (2001) and Fehse et al. (2004)

${ }^{\mathrm{e}}$ Weissinger et al. $(2011,2014)$

${ }^{f}$ One patient with GVHD achieved CR after administration of GCV and steroids

gBonini et al. (2007), Ciceri, Bonini et al. (2009), and Lupo-Stanghellini (2017)

${ }^{\mathrm{h}}$ Clinical outcome is measured in terms of T-cell immune reconstitution (evaluated as more than 100 circulating CD3+ $\mathrm{T}$ lymphocytes/ $\mu \mathrm{L}$ ) and pathogen-specific immunocompetence

${ }^{i}$ Four patients with GVHD achieved CR after administration of GCV and short-course low-dose steroids; two patients with GVHD achieved CR after GCV administration and IS

iZhan et al. (2013)

${ }^{k}$ Di Stasi et al. (2011) and Zhou et al. (2014)

${ }^{1} \mathrm{~T}$ cells were genetically engineered and depleted of host-reactive specificities before infusion

mElshoury et al. (2017)

cancer patients in Europe. Although when infused after haplo-HSCT TK-cells could be detected for more than 14 years (Oliveira et al. 2015), their persistence might be limited when cells are infused to immunocompetent patients, due to the viral origin of HSV-TK and to its subsequent immunogenicity in humans.
Alternative suicide genes were designed and tested in clinical trials (Table 60.2). iCasp9, in particular, is an innovative suicide gene based on human components and thus with a reduced risk of immunogenicity that was recently proposed and successfully tested in clinical trials (Table 60.2) (Di Stasi et al. 2011; Zhou et al. 2014). Overall, 
more than half of the patients who had received suicide gene-expressing donor $\mathrm{T}$ cells experienced a clinical benefit in terms of immune reconstitution and GVL (Table 60.2). Of notice, all cases of GVHD were completely controlled by the suicide gene/prodrug systems (Table 60.2).

\subsection{CAR-T Cells}

\subsubsection{CAR-T Cells, Clinical Efficacy}

CARs are designer molecules comprised of several components: an extracellular antigen-binding domain, usually the variable light and heavy chains of a MoAb ( $\mathrm{scFv})$; a spacer and transmembrane region that anchors the receptor on the T-cell surface and provides the reach and flexibility necessary to bind to the target epitope; and an intracellular signaling module, most commonly CD3 zeta and one or more costimulatory domains that mediate T-cell activation after antigen binding, resulting in selective tumor cell killing.

The most advanced clinical development is the use of CARs specific for the B-lineage marker CD19. Several groups have demonstrated that CD19 CAR-T cells are able to induce durable complete remissions in patients with chemotherapy- and radiotherapy-refractory B-cell ALL, NHL, and CLL (Maude et al. 2014; Park et al. 2018; Turtle et al. 2017).

With longer follow-up, resistance mechanisms to CD19 CAR-T-cell therapy have become apparent, including the development of leukemia cell variants that lost their CD19 antigen expression, particularly in ALL. Several mechanisms may contribute to the development of this phenotype including lymphoid-to-myeloid transdifferentiation, selection of pre-existing CD19-low/CD19negative leukemia clones, and emergence of clones that lost the specific epitope targeted by the CD19-CAR due to alternative splicing (Gardner et al. 2016; Sotillo et al. 2015; Ruella and June 2016). In ALL, CD19-low/CD19negative leukemia cells may still express CD20, CD22, and/or CD123 that are being pursued as rescue antigens. A recent study highlighted the potential to re-induce remissions in patients that had relapsed with CD19-low/CD19-negative leukemia and subsequently received CD22 CAR-T cells (Fry et al. 2018). Unfortunately, CD22 itself is prone to internalization and downregulation, and indeed a significant proportion of patients experienced successive CD22-low/CD22negative leukemia relapse. At present, combinatorial targeting of CD19 with either CD20, CD22, or CD123 is being explored, either through bispecific CAR constructs with two scFvs in cis or through co-expression of two CAR constructs in the same T cells (Zah et al. 2016).

Clinical results obtained with CAR-T cells (Table 60.3) led to recent FDA approval of two CD19 CAR-T-cell products for the treatment of ALL and NHL. Both products are manufactured by viral gene transfer and made headlines due to their considerable market price and the complex logistics behind this treatment. This involves harvesting the patient's $T$ cells at a leukapheresis center, shipping to a centralized manufacturing facility to perform CAR gene transfer and T-cell expansion and return shipment of the cryopreserved cell product. There is a recent increase in the use of exportable manufacturing devices that are anticipated to provide on-site, point-of-care CAR-T cell manufacture to reduce costs and wait-time.

Another clinical proof-of-concept for CAR-Tcell therapy has been obtained in MM. The lead antigen for CAR-T cells in multiple myeloma is $\mathrm{B}$-cell maturation antigen (BCMA). A recent clinical trial with BCMA-specific CAR-T cells has highlighted their therapeutic potential with several PRs and CRs (Ali et al. 2016), and additional data from ongoing trials continue to emerge. Also, with BCMA, antigen downregulation and the emergence of myeloma cell variants with antigen loss were described, underscoring the need to explore additional target antigens, e.g., SLAMF7 (Gogishvili et al. 2017), CD44v6 (Casucci et al. 2013), and CD38 (Mihara et al. 2009).

\subsubsection{Side Effects and Their Management}

Results from pioneering clinical studies investigating CAR-T cells in patients with hematologi- 
Table 60.3 Clinical trials with CAR-T cells

\begin{tabular}{|c|c|c|c|c|c|c|c|c|}
\hline $\begin{array}{l}\text { Clinical } \\
\text { application } \\
\text { (reference) }\end{array}$ & Antigen & $\begin{array}{l}\text { No. } \\
\text { of } \\
\text { pat }\end{array}$ & $\begin{array}{l}\text { Clinical } \\
\text { response }\end{array}$ & Toxicity & $\begin{array}{l}\text { No. of T } \\
\text { cells } \\
\text { (infused/kg } \\
\text { BW) }\end{array}$ & CAR design & $\begin{array}{l}\text { Gene } \\
\text { transfer } \\
\text { vector }\end{array}$ & $\begin{array}{l}\text { Safety } \\
\text { technology }\end{array}$ \\
\hline $\mathrm{ALL}^{\mathrm{a}}$ & CD19 & 30 & $\begin{array}{l}90 \% \text { CR } \\
79 \% \\
\text { MRD }\end{array}$ & $\begin{array}{l}\text { B-cell aplasia } \\
\text { CRS } \\
\text { Neurotoxicity }\end{array}$ & $\begin{array}{l}0.76- \\
20 \times 10^{6}\end{array}$ & $\begin{array}{l}\text { FMC63 scFv } \\
\text { CD8 alpha } \\
\text { spacer } \\
\text { 4-1BB costim }\end{array}$ & Lentivirus & None \\
\hline $\mathrm{ALL}^{\mathrm{b}}$ & CD19 & 16 & $\begin{array}{l}88 \% \text { CR } \\
75 \% \\
\text { MRD }\end{array}$ & $\begin{array}{l}\text { B-cell aplasia } \\
\text { CRS } \\
\text { Neurotoxicity }\end{array}$ & $3 \times 10^{6}$ & $\begin{array}{l}\mathrm{SJ} 25 \mathrm{C} 1 \mathrm{scF} V \\
\mathrm{CD} 28 \mathrm{ECD} \\
\text { spacer } \\
\text { CD28 costim }\end{array}$ & Retrovirus & None \\
\hline $\mathrm{ALL}^{\mathrm{c}}$ & CD19 & 29 & $\begin{array}{l}93 \% \text { CR } \\
86 \% \\
\text { MRD }\end{array}$ & $\begin{array}{l}\text { B-cell aplasia } \\
\text { CRS } \\
\text { Neurotoxicity }\end{array}$ & $\begin{array}{l}2 \times 10^{5} \text { to } \\
2 \times 10^{7}\end{array}$ & $\begin{array}{l}\text { FMC63 scFv } \\
\text { IgG4 Hinge } \\
\text { spacer } \\
\text { 4-1BB costim }\end{array}$ & Lentivirus & $\begin{array}{l}\text { EGFRt } \\
\text { depletion } \\
\text { marker }\end{array}$ \\
\hline NHL/CLL ${ }^{d}$ & CD19 & 15 & $\begin{array}{l}53 \% \mathrm{CR} \\
26 \% \mathrm{PR}\end{array}$ & $\begin{array}{l}\text { B-cell aplasia } \\
\text { CRS } \\
\text { Neurotoxicity }\end{array}$ & $1-5 \times 10^{6}$ & $\begin{array}{l}\text { FMC63 scFv } \\
\text { CD28 ECD } \\
\text { spacer } \\
\text { CD28 costim }\end{array}$ & Retrovirus & None \\
\hline $\mathrm{NHL} \mathrm{CLL}^{\mathrm{e}}$ & CD19 & 32 & $\begin{array}{l}50 \% \text { CR } \\
72 \% \\
\text { ORR }\end{array}$ & $\begin{array}{l}\text { B-cell aplasia } \\
\text { CRS } \\
\text { Neurotoxicity }\end{array}$ & $\begin{array}{l}2 \times 10^{5} \text { to } \\
2 \times 10^{7}\end{array}$ & $\begin{array}{l}\text { FMC63 scFv } \\
\text { IgG4 Hinge } \\
\text { spacer } \\
\text { 4-1BB costim }\end{array}$ & Lentivirus & $\begin{array}{l}\text { EGFRt } \\
\text { depletion } \\
\text { marker }\end{array}$ \\
\hline $\operatorname{CLL}^{\mathrm{f}}$ & CD19 & 20 & $\begin{array}{l}21 \% \text { CR } \\
53 \% \mathrm{PR}\end{array}$ & $\begin{array}{l}\text { B-cell aplasia } \\
\text { CRS } \\
\text { Neurotoxicity }\end{array}$ & $\begin{array}{l}2 \times 10^{5} \text { to } \\
2 \times 10^{7}\end{array}$ & $\begin{array}{l}\text { FMC63 scFv } \\
\text { IgG4 Hinge } \\
\text { spacer } \\
\text { 4-1BB costim }\end{array}$ & Lentivirus & $\begin{array}{l}\text { EGFRt } \\
\text { depletion } \\
\text { marker }\end{array}$ \\
\hline $\mathrm{MM}^{\mathrm{g}}$ & CD19 & 10 & $\begin{array}{l}1 \mathrm{CR} \\
2 \mathrm{PR}\end{array}$ & $\begin{array}{l}\text { B-cell aplasia } \\
\text { CRS (mild) }\end{array}$ & $\begin{array}{l}1-5 \times 10^{7} \\
\text { (total) }\end{array}$ & $\begin{array}{l}\text { FMC63 scFv } \\
\text { CD8 alpha } \\
\text { spacer } \\
\text { 4-1BB costim }\end{array}$ & Lentivirus & None \\
\hline $\mathrm{MM}^{\mathrm{h}}$ & BCMA & 12 & $\begin{array}{l}1 \mathrm{CR} \\
1 \mathrm{PR} \\
2 \mathrm{VGPR}\end{array}$ & $\begin{array}{l}\text { Hematologic } \\
\text { (Cytopenia) } \\
\text { CRS } \\
\text { Neurotoxicity }\end{array}$ & $0.3-3 \times 10^{6}$ & $\begin{array}{l}\text { C11D5.3 scFv } \\
\text { CD28 ECD } \\
\text { spacer } \\
\text { CD28 costim }\end{array}$ & Retrovirus & None \\
\hline
\end{tabular}

$A L L$ acute lymphoblastic leukemia, $N H L$ non-Hodgkin lymphoma, $C L L$ chronic lymphocytic leukemia, $M M$ multiple myeloma, $B C M A$ B-cell maturation antigen, $C R$ complete remission, $M R D$ minimal residual disease, $P R$ partial remission, $V G P R$ very good partial remission, $C R S$ cytokine release syndrome, $k g$ kilogram, $B W$ body weight, $s c F v$ singlechain variable fragment, costim costimulatory domain, $I g G$ immunoglobulin $\mathrm{G}, E C D$ extracellular domain, EGFRt epidermal growth factor receptor (Wang 2011)

aMaude et al. (2014)

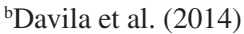

'Turtle et al. (2016)

${ }^{\mathrm{d}}$ Kochenderfer et al. (2015)

eTurtle et al. (2016)

${ }^{\text {f}}$ Turtle et al. (2017)

${ }^{\mathrm{g}}$ Garfall et al. (2015)

${ }^{\text {h} A l i ~ e t ~ a l . ~(2016) ~}$

cal cancers highlight the frequent occurrence of severe adverse reactions, which in some cases were fatal. The most obvious toxicity by CAR-T cells is the elimination of lineage cells expressing the target antigen of choice. For example, pro- found and, in some cases, long-lasting B-cell aplasia was observed after the infusion of CD19 CAR-T cells in patients with ALL, NHL, and CLL (Maude et al. 2014; Park et al. 2018; Turtle et al. 2017). By analogy, BCMA CAR-T cells are 
expected to induce plasma cell ablation in MM patients. The depletion of antibody-producing cells, or their precursors, in turn causes hypogammaglobulinemia, requiring constant supplementation with immunoglobulins.

Besides these expected on-target/off-tumor effects, a new class of on-target/on-tumor adverse reactions is represented by the cytokine release syndrome (CRS) and by neurotoxicity. CRS is initiated by CAR-T cell recognition of tumor cells, igniting the release of massive amounts of inflammatory cytokines, possibly by recruiting cells of the innate immunity. A master cytokine of the CRS is IL-6, as demonstrated by prompt and often complete response to the anti-IL-6 receptor monoclonal antibody tocilizumab. CRS symptoms range from high fever, headache, and myalgia to life-threatening cardiocirculatory and renal insufficiency. Clinical data reported so far utilize three slightly different systems for severity grading, which makes it difficult to draw meaningful comparisons in CRS liability between CAR-Tcell trials (Table 60.4). Nonetheless, there is generalized consensus on the fact that severe CRS is more frequent in ALL compared to NHL and that high tumor burden is an important risk factor.

Differently from CRS, the pathophysiology of neurotoxicity by CAR-T cells remains an uncharted territory and decisively worthy of further research, given its highly dismal prognosis, as demonstrated by several cases of lethal cerebral edema. Initially thought to be caused by tumor recognition by CAR-T cells within the brain, neurotoxicity is now recognized to be independent from leukemic localization to the CNS. Moreover, unresponsiveness to tocilizumab suggests that excessive IL-6 signaling may not be sufficient to explain neurotoxicity and that additional pharmacological measures should be investigated.

\subsection{TCR Gene Transfer and Future Perspectives}

In contrast to CARs that only bind surface molecules, TCRs recognize small pieces (peptides) derived from any cellular protein and presented by MHC molecules. Since the vast majority of tumor-specific/associated antigens are expressed intracellularly, they will only be addressable by TCRs, but not CARs. Moreover, therapeutically relevant cancer-driver mutations in most cases happen in intracellular proteins (e.g., signal transducers).

At the same time, the advantage of TCRs represents a major hurdle for broad clinical application: Any transgenic TCR only functions in the context of one specific HLA complex. Thus, in order to offer TCR-T-cell therapy to virtually all candidate patients, for each antigen a whole set of active TCRs will have to be established for different HLA molecules.

Table 60.4 CRS severity scoring systems

\begin{tabular}{|c|c|c|c|}
\hline & Penn scale & CTCAE & Lee (2014) \\
\hline Grade 1 & $\begin{array}{l}\text { Mild reaction treated with antipyretics } \\
\text { and/or antiemetics }\end{array}$ & $\begin{array}{l}\text { Mild reaction, no treatment } \\
\text { needed }\end{array}$ & $\begin{array}{l}\text { - Non-life-threatening reaction } \\
\text { responsive to symptomatic } \\
\text { treatment }\end{array}$ \\
\hline Grade 2 & $\begin{array}{l}\text { Moderate reaction requiring } \\
\text { hospitalization and IV therapy (no fluid } \\
\text { resuscitation) }\end{array}$ & $\begin{array}{l}\text { Moderate reaction } \\
\text { responsive to symptomatic } \\
\text { treatment within } 24 \mathrm{~h}\end{array}$ & $\begin{array}{l}\text { - Moderate reaction requiring } \\
\text { oxygen }<40 \% \text {, fluid } \\
\text { resuscitation, or low-dose } \\
\text { pressors } \\
\text { - Any G } 2 \text { organ toxicity }\end{array}$ \\
\hline Grade 3 & $\begin{array}{l}\text { Severe reaction requiring high-flow } \\
\text { oxygen or noninvasive lung ventilation, } \\
\text { fluid resuscitation, or low-dose pressors }\end{array}$ & $\begin{array}{l}\text { Prolonged reaction } \\
\text { nonresponsive to } \\
\text { symptomatic treatment }\end{array}$ & $\begin{array}{l}\text { - Severe reaction requiring } \\
\text { oxygen }>40 \% \text {, high-dose } \\
\text { pressors } \\
\text { - Any G3 organ toxicity }\end{array}$ \\
\hline Grade 4 & $\begin{array}{l}\text { Life-threatening reaction requiring } \\
\text { high-dose pressors and/or mechanical } \\
\text { ventilation }\end{array}$ & $\begin{array}{l}\text { Life-threatening reaction, } \\
\text { pressor, or ventilator } \\
\text { requirement }\end{array}$ & $\begin{array}{l}\text { - Life-threatening reaction } \\
\text { requiring mechanical } \\
\text { ventilation } \\
\text { - Any G4 organ toxicity }\end{array}$ \\
\hline
\end{tabular}


The first TCR gene therapies were applied to melanoma patients (MART-1 antigen), but meanwhile many cancers have been addressed. Based on their almost complete absence in adult tissues, cancer/testis antigens (MAGE, NY-ESO1) represent particularly promising targets. Many studies showed significant antitumor activity, but ontarget as well as off-target activities were associated with severe side effects, including mortality (Morris and Stauss 2016).

Genome editing has been proposed to improve efficacy and decrease side effects of TCR gene therapy. Editing might be used to knock out the endogenous TCR to increasing expression of the transgenic one and decreasing the mispairing risk between endogenous and transgenic TCR chains (potentially leading to autoreactive $\mathrm{T}$ cells) (Provasi et al. 2012). Moreover, targeted integration in the TCR locus can improve long-term expression of transgenic TCRs (Eyquem et al. 2017).

In conclusion, T-cell therapies have become a promising novel anticancer weapon. Their broad application will require (1) identification of additional targets, (2) availability of TCRs against established targets for many HLA molecules, and (3) improved methods for large-scale GMP production. All these points will become particularly relevant in concepts addressing multiple tumor neoantigens to decrease the likelihood of escape (Tran et al. 2017).

\section{Key Points}

- The cellular basis of cancer immune surveillance was demonstrated with the discovery of the nature of GVHD and its antileukemic effects.

- This observation was followed by the first successful attempts of adoptive immunotherapy using DLI to promote GVL.

- Several approaches of T-cell manipulation have been developed and tested to reduce the GVHD risk associated with allogeneic $\mathrm{T}$ cells. These strategies rely on the genetic manipulation of T cells or the use of suicide gene therapy.

- More recently, strategies based on the genetic transfer of tumor-specific T-cell receptors (TCRs) or chimeric antigen receptors (CARs) were developed to improve antitumor efficiency of $\mathrm{T}$ cells.

\section{References}

Ali SA, Shi V, Maric I, et al. T cells expressing an antiB-cell maturation antigen chimeric antigen receptor cause remissions of multiple myeloma. Blood. 2016;128:1688-700.

Bonini C, Ferrari G, Verzeletti S, et al. HSV-TK gene transfer into donor lymphocytes for control of allogeneic graft-versus-leukemia. Science. 1997;276:1719-24.

Casucci M, Nicolis di Robilant B, Falcone L, et al. CD44v6-targeted $\mathrm{T}$ cells mediate potent antitumor effects against acute myeloid leukemia and multiple myeloma. Blood. 2013;122:3461-72.

Ciceri F, Bonini C, Stanghellini MT, et al. Infusion of suicide-gene-engineered donor lymphocytes after family haploidentical haemopoietic stem-cell transplantation for leukaemia (the TK007 trial): a non-randomised phase I-II study. Lancet Oncol. 2009;10:489-500.

Di Stasi A, Tey SK, Dotti G, et al. Inducible apoptosis as a safety switch for adoptive cell therapy. N Engl J Med. 2011;365:1673-83.

Eyquem J, Mansilla-Soto J, Giavridis T, et al. Targeting a CAR to the TRAC locus with CRISPR/Cas9 enhances tumour rejection. Nature. 2017;543:113-7.

Fry TJ, Shah NN, Orentas RJ, et al. CD22-targeted CAR T cells induce remission in B-ALL that is naive or resistant to CD19-targeted CAR immunotherapy. Nat Med. 2018;24:20-8.

Gardner R, Wu D, Cherian S, et al. Acquisition of a CD19-negative myeloid phenotype allows immune escape of MLL-rearranged B-ALL from CD19 CART-cell therapy. Blood. 2016;127:2406-10.

Gogishvili T, Danhof S, Prommersberger S, et al. SLAMF7-CAR T cells eliminate myeloma and confer selective fratricide of SLAMF7+normal lymphocytes. Blood. 2017;130:2838-47.

Kolb HJ, Mittermüller J, Clemm C, et al. Donor leukocyte transfusions for treatment of recurrent chronic myelogenous leukemia in marrow transplant patients. Blood. 1990;76:2462-5.

Maude SL, Frey N, Shaw PA, et al. Chimeric Antigen Receptor $\mathrm{T}$ Cells for Sustained Remissions in Leukemia. N Engl J Med. 2014;371:1507-17. 
Mihara K, Yanagihara K, Takigahira M, et al. Activated T-cell-mediated immunotherapy with a chimeric receptor against CD38 in B-cell non-Hodgkin lymphoma. J Immunother. 2009;32:737-43.

Morris EC, Stauss HJ. Optimizing T-cell receptor gene therapy for hematologic malignancies. Blood. 2016;127:3305-11.

Oliveira G, Ruggiero E, Stanghellini MT, et al. Tracking genetically engineered lymphocytes long-term reveals the dynamics of $\mathrm{T}$ cell immunological memory. Sci Transl Med. 2015;7:317ra198.

Park JH, Rivière I, Gonen M, et al. Long-term follow-up of CD19 CAR therapy in acute lymphoblastic leukemia. N Engl J Med. 2018;378:449-59.

Provasi E, Genovese P, Lombardo A, et al. Editing T cell specificity towards leukemia by zinc finger nucleases and lentiviral gene transfer. Nat Med. 2012;18: 807-15.

Ruella M, June CH. Chimeric antigen receptor T cells for B cell neoplasms: choose the right CAR for you. Curr Hematol Malig Rep. 2016;11:368-84.

Sotillo E, Barrett DM, Black KL, et al. Convergence of acquired mutations and alternative splicing of CD19 enables resistance to CART-19 immunotherapy. Cancer Discov. 2015;5:1282-95.

Tran E, Longo DL, Urba WJ. A milestone for CAR T cells. N Engl J Med. 2017;377:2593-6.

Turtle CJ, Hay KA, Hanafi LA, et al. Durable molecular remissions in chronic lymphocytic leukemia treated with CD19-specific chimeric antigen receptormodified T cells after failure of ibrutinib. J Clin Oncol. 2017;35:3010-20.

Weiden PL, Flournoy N, Thomas ED, et al. Antileukemic effect of graft-versus-host disease in human recipients of allogeneic-marrow grafts. $\mathrm{N}$ Engl J Med. 1979;300:1068-73.

Zah E, Lin MY, Silva-Benedict A, et al. T cells expressing CD19/CD20 bispecific chimeric antigen receptors prevent antigen escape by malignant B cells. Cancer Immunol Res. 2016;4:498-508.

Zhou X, Di Stasi A, Tey SK, et al. Long-term outcome after haploidentical stem cell transplant and infusion of $\mathrm{T}$ cells expressing the inducible caspase 9 safety transgene. Blood. 2014;123:3895-905.

Open Access This chapter is licensed under the terms of the Creative Commons Attribution 4.0 International License (http://creativecommons.org/licenses/by/4.0/), which permits use, sharing, adaptation, distribution and reproduction in any medium or format, as long as you give appropriate credit to the original author(s) and the source, provide a link to the Creative Commons license and indicate if changes were made.

The images or other third party material in this chapter are included in the chapter's Creative Commons license, unless indicated otherwise in a credit line to the material. If material is not included in the chapter's Creative Commons license and your intended use is not permitted by statutory regulation or exceeds the permitted use, you will need to obtain permission directly from the copyright holder. 